\title{
How a Bookstore Retailer Survives During Covid-19 Pandemic with Omnichannel Strategy (a Bookstore Retail Case Study)
}

\author{
Caecilia Fitriani ${ }^{1}$, Florentina Kurniasari ${ }^{2}$, Noemi Silva ${ }^{3}$ \\ \{fitriani@student.umn.ac.id ${ }^{1}$, florentina@umn.ac.id ${ }^{2}$, nb_silva@yahoo.com $\left.{ }^{3}\right\}$ \\ Technology Management Department, Universitas Multimedia Nusantara, Indonesia ${ }^{1}$, \\ Technology Management Department, Universitas Multimedia Nusantara, Indonesia ${ }^{2}$, \\ Notre Dame of Marbel University, Philippines ${ }^{3}$
}

\begin{abstract}
The purpose of this study is to examine the urgency of using an omnichannel strategy for an established bookstore retailer to be survived in the Covid-19 pandemic. This study analyzed one of the biggest bookstore retailers in Indonesia named Gramedia. The omnichannel strategy was launched as an anticipation strategy of the decreasing sales volume of the bookstore which in return had a significant effect on the business performances. The omnichannel strategy was chosen because it is expected to increase the business revenue by maximizing the sales volume from all distribution channels both offline and online. Gramedia felt confident since the company had extensive resources in terms of technology infrastructure support and experiences in delivering superior quality and innovative services to the customers.
\end{abstract}

Keywords: Omni Channel, Online Shopping, Customer Experience, Covid-19, Organization Performances

\section{Introduction}

People nowadays are looking for a more convenient way of fulfilling their needs. Starting with food, clothes, and even hobbies items such as bicycles and even piano. They were intended to have less effort in their buying process, from considering the items until consuming. The pandemic of Covid-19 is driving this to escalation. The reluctance to contact other living things is getting worse, making the practicality of the buying process even more indispensable. The Indonesia government regulation (PSBB) to stop the spreading of the Coronavirus also made the business operation is not running well, including many retailers that are opened their stores in the shopping malls. Therefore, many retailers experienced a decreasing number of visitors who are shopping in their stores.

Gramedia is the biggest bookstore chain in Indonesia, with almost $80 \%$ of the market shares also experienced this difficult situation. It relied on the sales of its bookstores that operated in major shopping malls across the country. Gramedia started the business in 1970 as a bookstore but now expanded the business and positioning itself as a family store which not only selling books but also provides schools \& office supplies, hobbies items such as sports \& music as well.

Luckily for Gramedia, the company had established an integrative information system as a response to digital business disruption because of the growing trend of customer behavior 
in shopping online. Gramedia had established its online platform in 2010. In stores, they also increasing customer experience by providing Mobile POS, to help customers settle the transactions on the spot. Customers do not have to queue in the cashier line. Currently, Gramedia is in the project to prepare a self-check-out concept in one of their stores. The initiatives are driven by the Internal Auditor whose concern about the fraud that happened in the stores such as lost items, naughty cashiers, etc. The self-check-out process should reduce the risk, by providing sensors in the gate and equipped the items with RFID. Before the Covid19 pandemic, customer convenience was still a big consideration, whether they are able and prefer to do the self-check-out or would rather do the transactions with the help of the cashiers. After the pandemic, all of this became very clear. People today prefer to do things on their own, without involving other people. That is why self-check-out will be the most preferred way to close the transactions and expected to attract customers to visit the stores again.

This technology services assisted Gramedia in facing the decreasing sales volume from the bookstore business due to the Covid-19 pandemic and anticipating the growing number of customers who are shopping online. The following figure showed that there is a shifting customer purchase behavior in Indonesia during the pandemic Covid-19 since there is $92 \%$ of consumers have tried a new shopping behavior and 58\% adapted the new digital shopping method.

\section{Nearly all consumers have changed shopping behaviors, particularly digital shopping methods, since the start of COVID-19}

Have you used any of the following since COVID-19 started' $\%$ of respondents

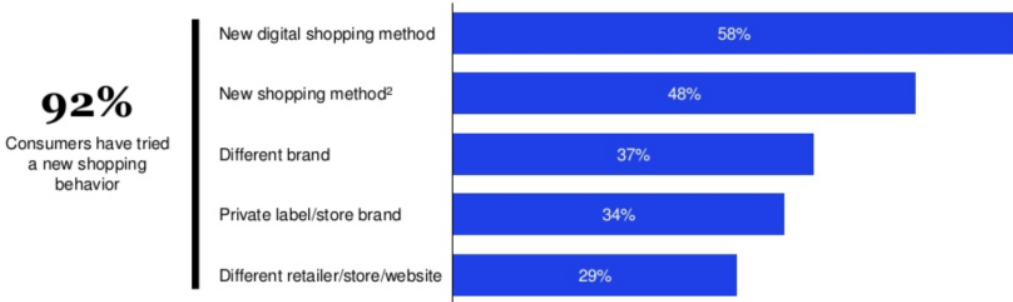

\section{$40 \alpha x=$}

Figure 1. Changing of Indonesia shopping behavior during the Covid-19 pandemic. Source: (McKinsey, 2020)

Also, during the Covid-19 pandemic, more Indonesian customers are preferred to purchase books, magazines, and newspapers through the online store as shown in Figure 2. 


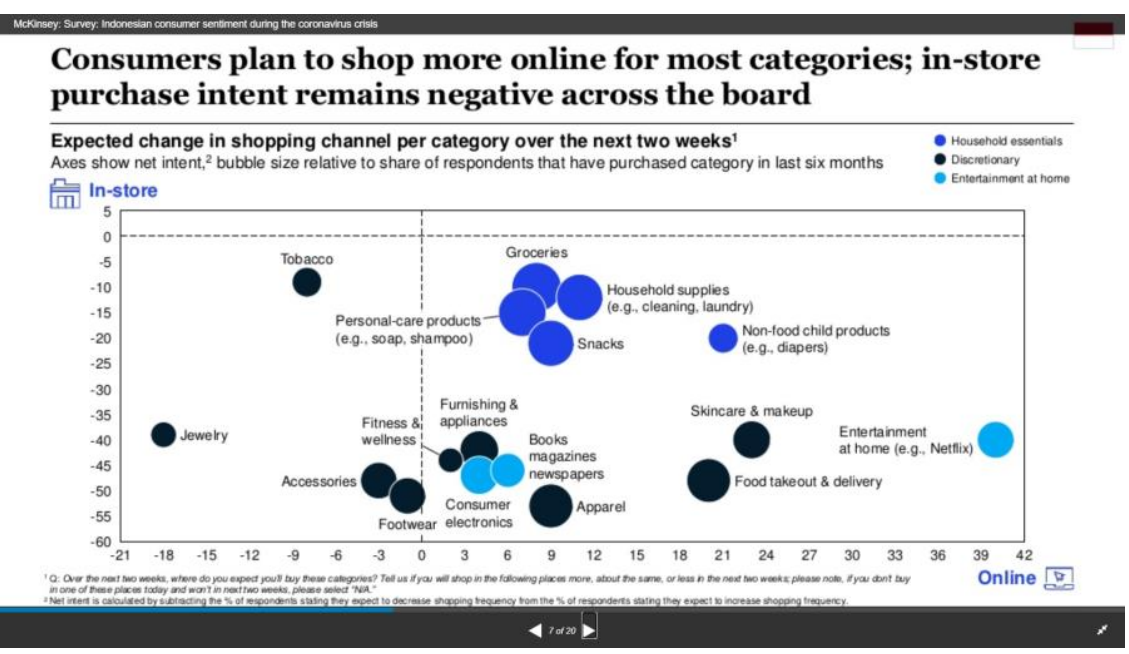

Figure 2. Expected change in the shopping channel during the Covid-19 pandemic in Indonesia. Source: (McKinsey, 2020)

Meanwhile, Figure 3 showed that the Covid-19 pandemic had encouraged Indonesian customers to purchase the products through an online system. There is a $43 \%$ growth of customers who purchase the books/magazines/newspaper through an online system. This growing number of online customers brought a huge opportunity for Gramedia to survive and at the same time expand its businesses.

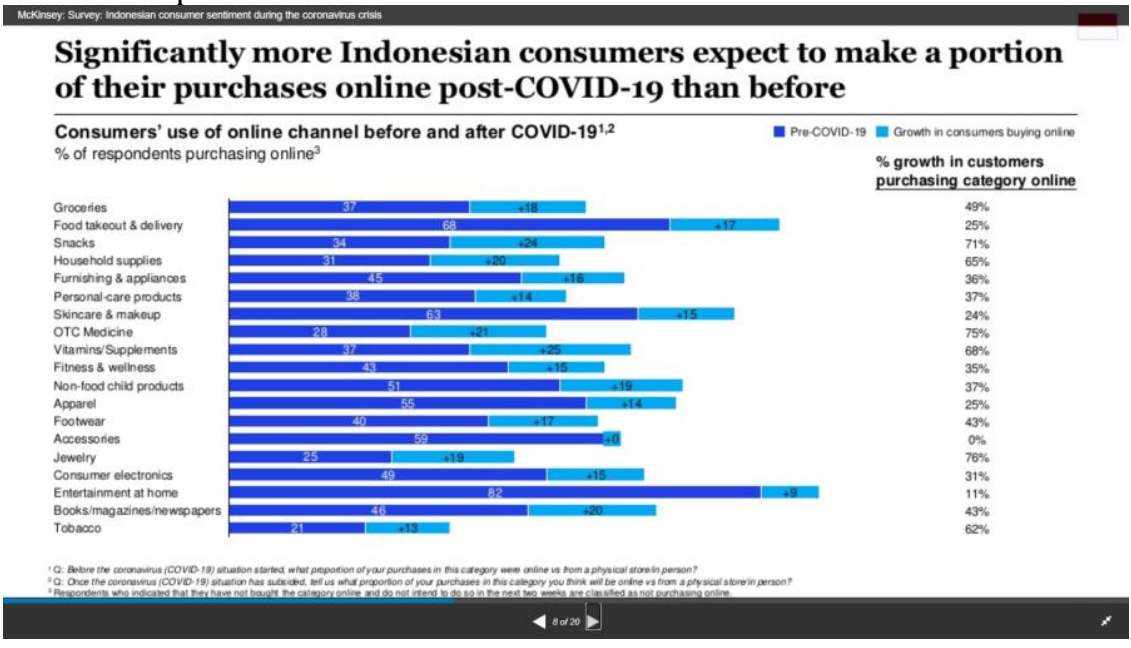

Figure 3. Comparison of Consumers' use of online channels before and after Covid-19. Source: (McKinsey, 2020)

To attract more customers to shop online, Gramedia had to start offering excellent services through innovation services. A recent study conducted by McKinsey explained that value and product availability are the key drivers for the customers to do online shopping. As stated in Figure $4,46 \%$ of customers are looking for better prices/promotion when doing online 
shopping, $38 \%$ of customers are looking for product availability and $28 \%$ of customers considered the delivery cost as an additional value.

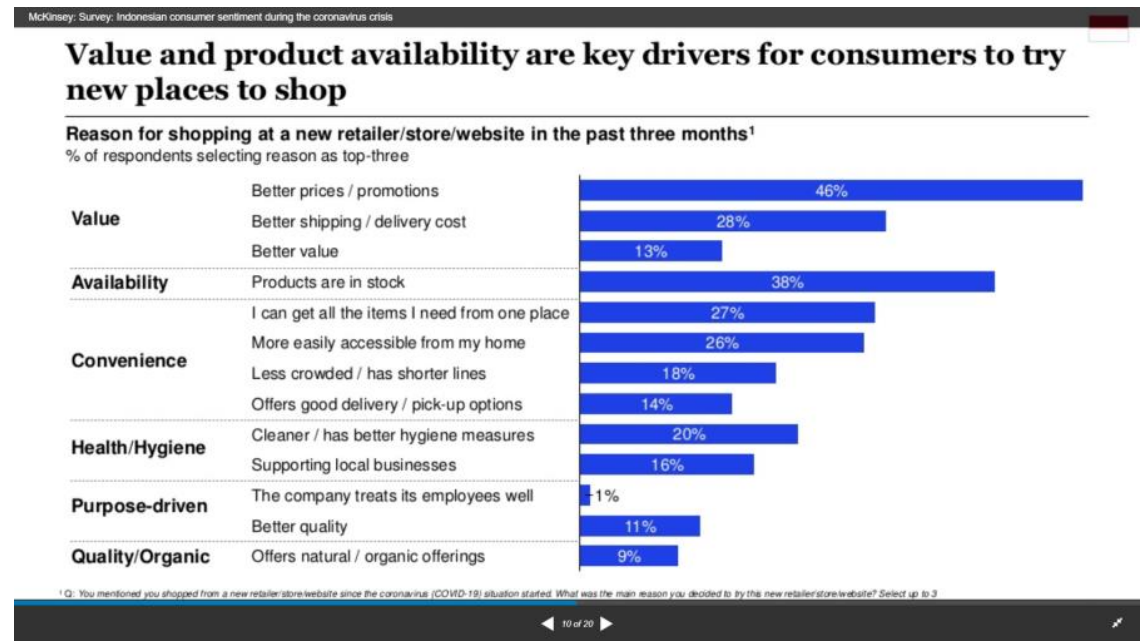

Figure 4. Customers key drivers in doing online shopping. Source: (McKinsey, 2020)

Therefore, to make the omnichannel strategy successfully implemented, Gramedia had to start intensifying its strategy by creating an innovative strategy to attract more customers to visit and purchasing the product online. The strategy covers both in terms of utilizing the information technology infrastructure and at the same time creating value as expected by the customers.

\section{Literature Review}

\subsection{Omnichannel}

Rigby was the first to mention the term in the academic literature by defining omnichannel retailing as: "an integrated sales experience that melds the advantages of physical stores with the information-rich experience of online shopping"[1].We observe that the definition was extended to the point that it involved not just the simultaneous use of channels, but the experience that derives from the integrated combination of them. The last attempt to define the term was by Levy, et al. (2013), who introduced "Omni retailing" as: "a coordinated multichannel offering that provides a seamless experience when using all of the retailer's shopping channels". They all agree that the prevalent notions are integrated/seamless experience using all channels. [2]

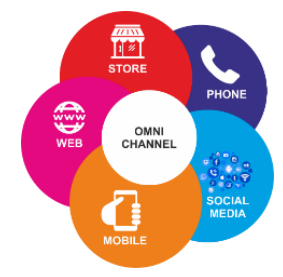

Figure 5. Omni Channel 


\subsection{Online Shopping}

Online shopping is an activity in a virtual place where people can easily explore product information, pictures, and promotions without being geographically inconvenienced. The ease of online shopping makes it a quick escape, with the expectation to feel better. These positive feelings gained during the online shopping process, thus, trigger the intentions to purchase, with potential leverage into impulsive buying behavior [3].

\subsection{Customer Experience}

A positive customer experience is crucial to the success of a business because a happy customer is one who is likely to become a loyal customer who can boost revenue. Customer experience is the internal and subjective response customers have to any direct or indirect contact with a company. Direct contact generally occurs during purchase, use, and service and is usually initiated by the customer. Indirect contact most often involves unplanned encounters with representations of a company's products, services, or brands and takes the form of word-ofmouth recommendations or criticisms, advertising, news reports, reviews, and so forth. [4]. Companies that systematically monitor customer experience can take important steps to improve it—and their bottom line. [4]

\subsection{Organization Performance}

The effectiveness of implementing the omnichannel strategy to increase organization performance in bookstore retailers like Gramedia will be determined by the KPI's of Sales, Productivity \& Inventory as described in Figure 6. To increase sales, customer experience is the most important variable to be improved. To increase productivity, the usage of space both online or in-store should be optimized as well as the productivity of people and any other cost. inventory also the main issue, to be handled effectively and efficiently. How to monitor the inventory turnover, the distribution of the inventory, from printing to warehouses to stores or fulfillment center.

\section{Gramedia Omni Channel}

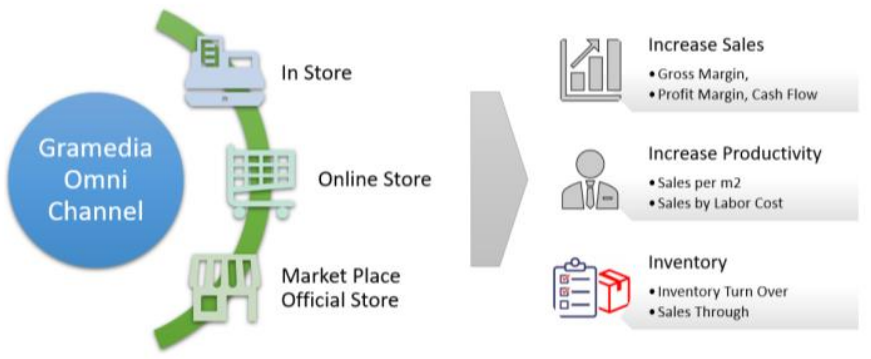

Figure 6. Conceptual Framework

\section{Result \& Discussion}

Many challenges are faced by Gramedia. They still need to improve the effectiveness and performance of their online platform. How they can capture customer behavior and interest, to make them come back to the platform and do more buying. What should be considered to give more convenient experience, such as implementing the $\mathrm{O} 2 \mathrm{O}$ concept (Online to Offline), to 
accommodate people who want to get the items without additional delivery fee, since they lived near one of the Gramedia stores. How to make sure the accuracy of stock information in the store. Should they differentiate the stock of online stores or just simply define one store as a fulfillment center. For an online platform, how to handle national wide big promotion events like HARBOLNAS (Hari Belanja Online Nasional), where the volume of transactions might reach 20,000 transactions per day. Another channel that Gramedia already uses is to become an official store in the marketplace that already has enormous visitors such as Tokopedia, Shopee, etc.

\subsection{In-Store Experience}

Gramedia has more than 120 stores in almost every big city in Indonesia. Most of the stores are in a mall or plaza, but there is also the building of a one-stop solution called Gramedia World. All the strategies to make classification of the stores are to accommodate customer behavior in the respective area. The Gramedia world is mostly located in a residential area where there is a family who needs a short time vacation near their houses. Therefore, Gramedia World provides not just a bookstore, school, or office stuff stores, but also a café, restaurant, and soft play arena for kids.

Mobile POS. For stores in malls or office buildings, Gramedia realizes that people have a very limited time to come to the store to get what they need. To increase customer convenience, Gramedia provides Mobile POS solutions. It is mobile check-out solutions for the customer who is willing to settle the transactions anywhere. They do not have to look and go to the cashier (POS) location and then make a queue there. Mobile POS is handled by a cashier who gives attention to the customer that already picked an item and looks like they are ready to go to the cashier outlet for making a payment. The mobile cashier will offer the customer whether they will close the transaction with their help right away or prefer to go to the cashier outlets. If the customer agrees then the mobile cashier will scan the items with the mobile POS, then settle the payment which only receives a cashless payment, and then offers the customer a bag to bring the items, or they just simply go with the item in their bag. This experience is making all the busy customers very happy and gives the added value which is less time consuming for them.

Self-Check-Out. While Mobile POS is an accommodating customer, who has limited time with a small number of items, Gramedia thinks of another solution for the customer who is also in a hurry, but with a basket of items and happy to do the transactions by themselves. The solution is the self-check-out kiosk. In the first place, the background of these solutions is to decrease the lost items that happened in the stores. This might be caused by a customer who leaves the store without paying the item, or by the cashier who has not finished the payment settlement in the POS but happened to receive the payment from the customer who didn't care about the receipt at all. The value of the lost items in a year is very significant and has been realized that his will impact the sales performance as well. This project is started at the end of 2019 and should be implemented before the school year started in July 2020. At that time, the self-checkout goals are more in the security aspect rather than a customer perspective. But of course, in designing the process of self-checkout in-store, Gramedia also considered the customer convenient experience. This is very important. There are three main preparation should be done. First, all items should be attached by an RFID sticker. Second, put the censored gate in the exit door to read the items with the RFID sticker that is not released by the payment process yet. The third one is the self-checkout kiosk which consists of an RFID scanner, the touch screen to 
show the items scanned, and a payment device such as an EDC or card reader to validate the payment. The challenge is not only to make the kiosk are easy to use by all kind of customers but also how to make the sensor gate effective, it should be sensitive but not annoying the customer. After pandemic Covid-19, people are very concerned with their distance from each other. Many stores should apply entryway separated with an exit way based on government regulation. These new normal conditions are giving us unintentional benefit. By dividing the entrance and the exit way, the investment of the sensor gate can be reduced. It can now focus on the exit way only. Thus, making the project of implementing the self-check-out concept in the store will be much easier and cost-effectively. With new normal, where people are avoiding to meet strangers such as cashier in-store, etc., Gramedia is very optimistic that the self-checkout solutions will become the most preferable and convenient way for the customer to shop instore as well as increasing the security of the stores.

\subsection{Online Stores}

Gramedia has started to sell the books online, since 2010. At that time, in Indonesia people are not used to buy books online. In 2015, when online shopping is increasing very fast, Gramedia acquired an e-commerce platform to provide a better online shopping experience for the customer. But then, to align with business needs, the acquired platform has some limitations to be customed and modified. Therefore, Gramedia builds a new IT Team to develop its ecommerce platform. Until now Gramedia.com platform is improving to become the most preferable platform to buy books online. Another challenge faced by Gramedia.com is to determine how to handle the stock of items while maintaining an omnichannel experience. In the beginning, all items displayed on an online platform are the same items as in offline stores. The stocks are updated from all over stores. This has run well in the normal traffic seasons. The deviations of stock status are not disturbing the customer. If the items in one store are not accurate, they can still fulfill the order from another store. The problems occur when there is a big event of online shopping promotions national wide. Where there are thousands of orders come in a day. The information of available stocks should be accurate. When it comes to a huge volume of transactions, there is no time and resource to look at the items in stores. This becomes a disaster. Learned from this lesson, Gramedia now sets some stores to become a fulfillment center. This means the online items will be picked up from those fulfillment centers only. The available stocks will be updated from those locations. After that, Gramedia does not worry anymore to handle the big promotion event such as HARBOLNAS (Hari Belanja Online Nasional).

\section{References}

[1] D. Rigby, “The Future of Shopping,” Harv. Bus. Rev., vol. 89, Jan. 2011.

[2] C. Lazaris, "From Multichannel to " Omnichannel " Retailing : Review of the Literature and Calls for Research," no. October, 2014, doi: 10.13140/2.1.1802.4967.

[3] M. Dharmesti, T. Rasika, S. Dharmesti, S. Kuhne, and P. Thaichon, "Understanding online shopping behaviours and purchase intentions amongst millennials," no. August, 2019, doi: 10.1108/YC-12-2018-0922.

[4] C. Meyer and A. Schwager, "Understanding Customer Experience Customer Experience," 2007. 